\title{
Influence of tectonic uplift-erosion on formation pressure
}

\author{
Xu Hao ${ }^{1 *}$, Zhang Junfeng ${ }^{2}$, Jia Chengzao ${ }^{3}$, Tang Dazhen ${ }^{1}$ and Yin Wei ${ }^{4}$ \\ ${ }^{1}$ School of Energy Resources, Key Laboratory of Marine Reservoir Evolution and Hydrocarbon Accumulation Mechanism, \\ China University of Geosciences, Beijing 100083, China \\ ${ }^{2}$ PetroChina Exploration and Production Company, Beijing 100007, China \\ ${ }^{3}$ PetroChina Co. Ltd., Beijing 100007, China \\ ${ }^{4}$ Research Institute of Petroleum Exploration and Development, Beijing 100083, China
}

(C) China University of Petroleum (Beijing) and Springer-Verlag Berlin Heidelberg 2010

\begin{abstract}
The formation of abnormally low-pressure hydrocarbon reservoirs in petroliferous basins has a close relationship with tectonic uplift and the consequent erosion. In order to understand abnormally low-pressure reservoirs and to provide a scientific basis for exploration and development, we established, through numerical simulation and theoretical analysis, a set of equations for the formation pressure in a closed system influenced by uplift-erosion, discussed the relationship between the genesis of abnormal pressure and uplift-erosion, and put forward the concept of balance pressure $\left(P_{\mathrm{b}}\right)$. The results showed that abnormally high pressure coefficient may form when the current formation pressure was higher than $P_{\mathrm{b}}$, and abnormally low pressure may form when the current formation pressure was lower than $P_{\mathrm{b}}$. In the Santanghu Basin, the current formation pressure of abnormally low pressure reservoirs is lower than $P_{\mathrm{b}}$, so tectonic uplift-erosion leads to the decrease of the pressure coefficient. There is a positive correlation between the pressure drop caused by the decrease of fluid temperature and the rebound of rock porosity and strata erosion. Calculation results indicated that the reservoir pressure of Jurassic strata in the Santanghu Basin was decreased by 11.6-17.1 MPa due to tectonic uplift-erosion during the Late Yanshanian period.
\end{abstract}

Key words: Uplift-erosion, formation pressure, temperature decrease, porosity rebound, abnormally low pressure, Santanghu Basin

\section{Introduction}

Research into the formation and evolution history of reservoir pressure has always been a focus of petroleum geology. In recent years, with the discovery of more and more abnormally low-pressure reservoirs in China and other countries (Bachu and Underschultz, 1995; He et al, 2000; Michael and Bachu, 2001; Zeng et al, 2002; Sorenson, 2005; Dai et al, 2003; Yuan and Liu, 2005; Zhang, 2007; Zhang et al, 2009), the change in formation pressure caused by tectonic uplift-erosion and its contribution to petroleum accumulation have aroused wide concern (Luo and Vasseur, 1992; Parks and Toth, 1995; Xie et al, 2003; Jiang et al, 2004; Tian et al, 2007; $\mathrm{Xu}$ et al, 2009). Previous research indicates that tectonic uplift-erosion will result in an increase in porosity as the confining pressure on the rock is relaxed, causing a rebound of porosity towards the levels before the rock is compressed under higher confining pressure (Neuzil, 1993; Peterson, 1958; Jiang et al, 2007) and decrease of fluid

*Corresponding author. email: xuhao600@163.com

Received August 11, 2009 temperature (Xia et al, 2001; Wu et al, 2006; Zhang et al, 2004), causing a decrease of formation pressure. However, the ratio of formation pressure to hydrostatic pressure, namely pressure coefficient, is usually used to define the abnormality of formation pressure. Therefore, we think that several problems exist. Will the pressure coefficient surely decrease, since tectonic uplift-erosion can cause a decrease in reservoir pressure? Will it definitely lead to abnormally low pressure? Can it produce relatively high pressure? What conditions should be met before it generates abnormally low pressure? In this paper, numerical simulation and case analysis are used to discuss the action mechanism of tectonic uplift-erosion on formation pressure in depth.

\section{Basic theories}

The formation pressure in different systems is controlled by different factors, so the influence of tectonic uplift-erosion on formation pressure is discussed for closed and open systems. The following different sets of circumstances can exist before and after strata uplift-erosion: (1) It is a closed system before uplifting and an open system after that; (2) It is a closed system before and after uplifting; (3) It is an open 
system before uplifting and a closed system after that; (4) It is an open system before and after uplifting. Among them, for circumstances (1) and (4), the current formation pressure is controlled by hydrostatic pressure (Xu et al, 2008). For circumstance (2), current formation pressure is controlled by the rebound of rock porosity and decrease in temperature. For circumstance (3), though current formation pressure is controlled by the rebound of rock porosity and decrease in temperature, the buried depth of reservoir when an open system is converted into a closed system should be viewed as the starting point for calculating the actual uplifting height, and it follows the action of the phreatic water table on reservoir pressure before the conversion. Therefore, this paper will center on the change in formation pressure during the uplift-erosion in a closed system (circumstance (2)).

Firstly, it is assumed that formation fluids are all in the liquid state and the classic equation of liquid state applies:

$$
V=V_{0}\left[1+\alpha_{\mathrm{f}}\left(T-T_{0}\right)-\beta_{\mathrm{f}} p\right]
$$

where, $\alpha_{\mathrm{f}}$ is the liquid expansion coefficient $\left(\mathrm{K}^{-1}\right) ; \beta_{\mathrm{f}}$ is the liquid compression coefficient $\left(\mathrm{Pa}^{-1}\right) ; V_{0}$ and $T_{0}$ are respectively the volume and temperature of liquid under initial condition; and $V, T$ and $p$ are respectively liquid states after the change and their units are $\mathrm{m}^{3}, \mathrm{~K}$ and $\mathrm{Pa}$ respectively.

The following equation can be derived from Eq. (1):

$$
\beta_{\mathrm{f}} p=\alpha_{\mathrm{f}}\left(T-T_{0}\right)+\left(V_{0}-V\right) / V_{0}
$$

where, $T-T_{0}$ is temperature variation and is represented by $\Delta T\left({ }^{\circ} \mathrm{C}\right)$ and $\left(V-V_{0}\right) / V_{0}$ is the rate of liquid volume change. The rate of fluid volume change under closed conditions is equal to the rate of pore volume change (Chilingar et al, 2002), then $\left(V_{0}-V\right) / V_{0}=\beta_{\mathrm{r}}(\delta-p)$, where $\delta$ is the overburden load pressure $(\mathrm{Pa})$ and $\beta_{\mathrm{r}}$ is pore volume compressibility $\left(\mathrm{Pa}^{-1}\right)$. Consequently, Eq. (2) can be represented by:

$$
p=\frac{\alpha_{\mathrm{f}}}{\beta_{\mathrm{f}}+\beta_{\mathrm{r}}} \Delta T+\frac{\beta_{\mathrm{r}}}{\beta_{\mathrm{f}}+\beta_{\mathrm{r}}} \delta
$$

The average positive pressure of horizontal strata is $\delta=\frac{2}{3} \delta_{x}+\frac{1}{3} \delta_{z}$, where $\delta_{x}$ represents the horizontal pressure component $\left(\delta_{x}=\delta_{y}\right)$ and $\delta_{z}$ is the vertical pressure component.

The horizontal bearing stress is $\delta_{x}=\delta_{y}=\frac{v}{1-v} \delta_{z}$ and then the total overburden load pressure is equal to:

$$
\delta=\frac{1}{3}\left(\frac{1+v}{1-v}\right) \delta_{z}
$$

where, $v$ is Poisson's ratio and $\delta_{x}$ is the change in the vertical component of stress during the erosion. With the change in sedimentary loading, $\delta_{x}$ can be represented by:

$$
\Delta \delta=\frac{1}{3}\left(\frac{1+v}{1-v}\right) g \rho_{\mathrm{r}} \Delta h
$$

where, $\Delta h$ is thickness of strata eroded during tectonic uplifting $(\mathrm{m})$ and $\rho_{\mathrm{r}}$ is average density of overlying strata $\left(\mathrm{kg} / \mathrm{m}^{3}\right)$

Through merging Eq. (5) into Eq. (3), the following equation can be obtained:

$$
\Delta p=\frac{1}{3}\left(\frac{1+v}{1-v}\right) \frac{\beta_{\mathrm{r}}}{\beta_{\mathrm{f}}+\beta_{\mathrm{r}}} g \rho_{\mathrm{r}} \Delta h+\frac{\alpha_{\mathrm{f}}}{\beta_{\mathrm{f}}+\beta_{\mathrm{r}}} \Delta T
$$

where, $\Delta p$ represents the pressure change caused by strata uplift-erosion $(\mathrm{Pa})$. The first item stands for pore pressure change $\left(\Delta p_{1}\right)$ caused by the change in the load of overlying strata.

$$
\Delta p_{1}=\frac{1}{3}\left(\frac{1+v}{1-v}\right) \frac{\beta_{\mathrm{r}}}{\beta_{\mathrm{f}}+\beta_{\mathrm{r}}} g \rho_{\mathrm{r}} \Delta h
$$

The second item represents the pore pressure change $\left(\Delta p_{2}\right)$ caused by temperature variation during the uplift-erosion.

$$
\Delta p_{2}=\frac{\alpha_{\mathrm{f}}}{\beta_{\mathrm{f}}+\beta_{\mathrm{r}}} \Delta T
$$

If the geothermal gradient stays unchanged and the decrease of temperature is caused by tectonic uplifting, $G=\frac{100 \Delta T}{\Delta h}$, where $G$ is geothermal gradient $\left({ }^{\circ} \mathrm{C} / 100 \mathrm{~m}\right)$. Consequently, Eq. (8) can be converted into:

$$
\Delta p_{2}=\frac{\alpha_{\mathrm{f}} G}{100\left(\beta_{\mathrm{f}}+\beta_{\mathrm{r}}\right)} \Delta h
$$

From Eq. (6), two basic factors which make the fluid pressure of strata drop are decreases in the overburden load and temperature. From Eqs. (7) and (8), the decrease of formation pressure has a positive correlation with the decrease of temperature and the intensity of tectonic uplifterosion. However, can the two factors cause the decrease in pressure coefficient? Namely, will it produce abnormally low pressure? This will be analyzed in depth.

\section{Analysis of the influence of pore rebound on formation pressure}

When overlying strata are eroded and vertical stress decreases, the rock matrix will rebound like an elastic solid, which will increase the pore volume (and hence the porosity) and result in a decrease of fluid pressure (Zou et al, 2003). Through Eq. (7), it is ascertained that the decrease in overburden load will lead to pressure drop.

To study the influence of pore rebound caused by strata erosion on abnormally low pressure, we start with a definition of abnormally low pressure, study the change in pressure coefficient caused by the decrease in overburden load when the temperature variation is not considered, and analyze the characteristics of the change in pressure coefficient after the strata are eroded, namely the contribution of pressure drop simply caused by erosional rebound of the formation.

By definition, it is assumed that the current pressure coefficient $C$ is equal to $p / \rho_{\mathrm{w}} g h$ and then the pressure coefficient before tectonic uplifting is:

$$
C_{\mathrm{o}}=\frac{p+\Delta p_{1}}{\rho_{\mathrm{w}} g(h+\Delta h)}
$$

where, $\rho_{\mathrm{w}}$ is the density of formation water, $\Delta h$ is erosion thickness and $\Delta p_{1}$ is the decrease of pressure caused by the uplift-erosion.

Then, the change in pressure coefficient before and after uplift-erosion is: 


$$
C / C_{\mathrm{o}}=\frac{p(h+\Delta h)}{h\left(p+\Delta p_{1}\right)}
$$

When $C / C_{\mathrm{o}}$ is more than 1 , the uplift-erosion tends to produce high pressure coefficient. When $C / C_{\mathrm{o}}$ is less than 1 , the uplift-erosion tends to generate abnormally low pressure. When $C / C_{\mathrm{o}}$ is equal to 1 , the pressure coefficient stays unchanged before and after uplift-erosion, and the formation pressure at that time is defined as balance pressure $p_{1 \mathrm{~b}}=\frac{1}{3}\left(\frac{1+v}{1-v}\right) \frac{\beta_{\mathrm{r}}}{\beta_{\mathrm{f}}+\beta_{\mathrm{r}}} h$ and has a linear relationship with burial depth of the strata.

\section{Analysis of the influence of temperature drop on formation pressure}

During tectonic uplifting, the temperature factor is nonnegligible (Swarbrick and Osborne, 1998). As the temperature of strata decreases, the fluid will shrink and its volume will decrease, resulting in fluid pressure drop. The influence of temperature decrease on formation pressure can be determined with Eq. (9). To study the influence of temperature decrease on the pressure coefficient, we undertook further analysis and found that according to Eq. (8), the change in pressure coefficient before and after temperature decrease can be represented as:

$$
C / C_{\mathrm{o}}=\frac{p(h+\Delta h)}{h\left(p+\Delta p_{2}\right)}=\frac{p(h+\Delta h)}{h\left(p+\frac{\alpha_{\mathrm{f}}}{\beta_{\mathrm{f}}+\beta_{\mathrm{r}}} \Delta T\right)}
$$

It is assumed that pores in a stratum are filled with formation water, the density of rock $\left(\rho_{\mathrm{r}}\right)$ is $2,300 \mathrm{~kg} / \mathrm{m}^{3}$, the average pore volume compressibility $\left(\beta_{\mathrm{r}}\right)$ is $26 \times 10^{-4} \mathrm{MPa}^{-1}$, average compressibility of formation water $\left(\beta_{\mathrm{f}}\right)$ is $5 \times 10^{-4} \mathrm{MPa}^{-1}$, and the average coefficient of thermal expansion $\left(\alpha_{\mathrm{f}}\right)$ is $5 \times 10^{-4} \mathrm{~K}^{-1}$. When only temperature is taken into consideration, it is assumed that the depth stays unchanged before and after temperature variation, and then Eq. (12) can be converted into:

$$
C / C_{\mathrm{o}}=\frac{p}{p+0.16 \Delta T}
$$

From Eq. (13), the temperature decrease will cause the decreases of formation pressure and pressure coefficient simultaneously. The greater the temperature reduction, the larger will be the decrease in formation pressure coefficient (see Fig. 1). It indicates that temperature decrease can easily produce abnormally low pressure.

\section{Analysis of the influence of tectonic uplift- erosion on formation pressure}

In the above paragraphs, the influence of pore rebound and temperature decrease on the formation pressure is discussed. However, in real geological process, the two factors often influence the formation pressure together and can be represented as follows:

$$
\Delta p=\left[\frac{1}{3}\left(\frac{1+v}{1-v}\right) \frac{\beta_{\mathrm{r}}}{\beta_{\mathrm{f}}+\beta_{\mathrm{r}}} g \rho_{\mathrm{r}}+\frac{\alpha_{\mathrm{f}} G}{100\left(\beta_{\mathrm{f}}+\beta_{\mathrm{r}}\right)}\right] \Delta h
$$

The change in pressure coefficient before and after the

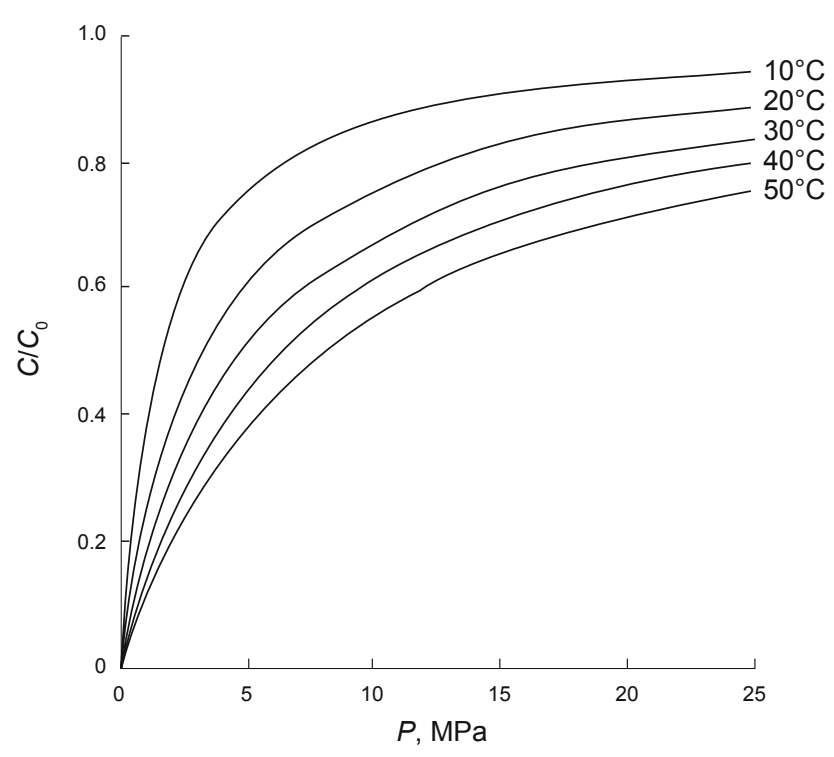

Fig. 1 Diagram of the relation between temperature decrease and the change of pressure coefficient

uplifting is:

$$
\begin{aligned}
& C / C_{\mathrm{o}}=\frac{p(h+\Delta h)}{h(p+\Delta p)} \\
& =\frac{p(h+\Delta h)}{h\left\{p+\left[\frac{1}{3}\left(\frac{1+v}{1-v}\right) \frac{\beta_{\mathrm{r}}}{\beta_{\mathrm{f}}+\beta_{\mathrm{r}}} g \rho_{\mathrm{r}}+\frac{\alpha_{\mathrm{f}} G}{100\left(\beta_{\mathrm{f}}+\beta_{\mathrm{r}}\right)}\right] \Delta h\right\}}
\end{aligned}
$$

When $C / C_{\mathrm{o}}$ is more than 1 , the uplift-erosion tends to produce high pressure coefficient. When $C / C_{0}$ is less than 1 , the uplift-erosion tends to generate abnormally low pressure. When $C / C_{\text {o }}$ is equal to 1 , the pressure coefficient stays unchanged before and after the uplift-erosion and the balance pressure can be represented as:

$$
p=\left[\frac{1}{3}\left(\frac{1+v}{1-v}\right) \frac{\beta_{\mathrm{r}}}{\beta_{\mathrm{f}}+\beta_{\mathrm{r}}} g \rho_{\mathrm{r}}+\frac{\alpha_{\mathrm{f}} G}{100\left(\beta_{\mathrm{f}}+\beta_{\mathrm{r}}\right)}\right] h
$$

It is assumed that geothermal gradient is $3^{\circ} \mathrm{C} / 100 \mathrm{~m}$, and if $G$ is substituted by the assumed parameter, Eq. (15) can be changed into:

$$
C / C_{\mathrm{o}}=\frac{p(h+\Delta h)}{h(p+0.0157 \Delta h)}
$$

Based on Eq. (17), the relationship between the pressure coefficients of strata with different burial depths and erosion thickness can be derived (see Fig. 2). From Fig. 2, although tectonic uplift-erosion may make the pressure drop a little, the pressure coefficient has two tendencies, namely either to increase or decrease, and all change curves of pressure coefficient intersect at one point. This point indicates that when the formation pressure meets a specific condition, the pressure coefficient stays unchanged regardless the intensity of tectonic uplift-erosion, and we define it as balance pressure $\left(P_{\mathrm{b}}\right)$ during tectonic uplift-erosion.

When the current formation pressure is equal to the balance pressure, the pressure coefficient stays unchanged although the formation pressure will drop after tectonic uplifterosion. When the current formation pressure is lower than 

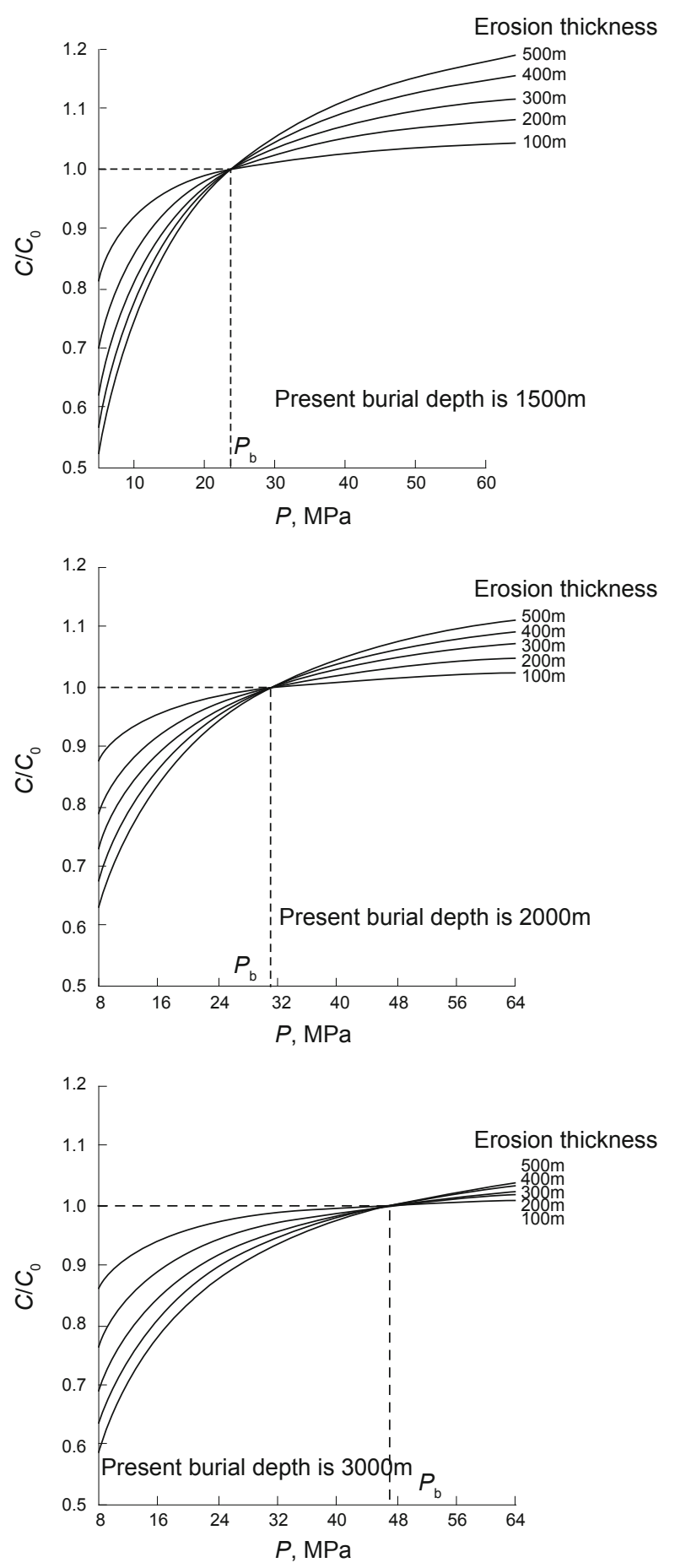

Fig. 2 Relation diagram of erosion thickness and pressure coefficient at different depths

the balance pressure, both the formation pressure and pressure coefficient will decrease after tectonic uplift-erosion. The larger the amplitude of tectonic uplift-erosion, the larger will be the decrease in pressure coefficient. When the formation pressure is higher than the balance pressure, the pressure coefficient will increase although the formation pressure will decrease after tectonic uplift-erosion. The higher the intensity of tectonic uplift-erosion, the higher will be the increase in pressure coefficient. It indicates that tectonic uplift-erosion does not always produce abnormally low pressure and whether it will cause a decrease in pressure coefficient or not is determined by the relationship between the formation pressure and balance pressure. It is noteworthy that although balance pressure theoretically exists, the current formation pressure can be equal to the balance pressure only when many factors are well coupled. Therefore, the current formation pressure is unlikely to equal the balance pressure and is almost always higher or lower than the balance pressure.

\section{An example from the Santanghu Basin}

\subsection{Geologic background}

The Santanghu Basin lies in the northeast of Xinjiang Uyghur Autonomous Region, China and has an area of $2.3 \times 10^{4} \mathrm{~km}^{2}$. The basin pattern is one of two uplifts and one depression and can be divided into three tectonic units, namely the NE thrust fold belt, central depression and SW thrust fold belt. The central depression belt consists of four uplifts and five depressions (see Fig. 3). The basement of the basin is Carboniferous and Permian, and the caprock mainly consists of middle Cenozoic. The sedimentary rock is over 3,000 $\mathrm{m}$ thick (see Table 1). Over ten years of exploration, considerable petroleum reserves have been discovered in Jurassic reservoirs. However, due to low reservoir pressure, insufficient producing energy and high reservoir heterogeneity, oil and production tests have not been favorable and exploration and development of oilfields have proved difficult. The widely-spread abnormally low pressure in Jurassic reservoirs has a close relationship with tectonic uplift-erosion, so in-depth research on the influence of tectonic uplift-erosion on the formation pressure of Jurassic strata is significant for the understanding of the genesis of abnormally low-pressure oil reservoirs and for guiding the exploration and development of oil reservoirs.

The Santanghu Basin experienced a stage of Carboniferous to early Permian basement evolution, one of late Permian to early Cretaceous basin evolution and a basin reconstruction stage since the late Cretaceous. The basin formation and evolution stage can be divided into three parts, namely extensional faulted depression basin after the orogenies of the late Permian, extension-compression at the end of Triassic, and depression in the early and middle Jurassic and late Jurassic to early Cretaceous compression. In terms of the whole basin evolution, the two tectonic movements during the late Hercynian and late Yanshanian periods are the largest and the one during late Yanshanian period has an important influence on the formation pressure of Jurassic strata (see Fig. 4).

\subsection{Characteristics of pressure system}

During this research, drill stem test (DST) data from over 20 wells have been collected and the data on the formation pressure are mainly from the Jurassic Badaowan, Xishanyao, Toutunhe and Qigu Formations. The analysis shows that the formation pressure of the Jurassic reservoir increases with depth, and the pressure coefficient is 0.48 0.92 , falling into the abnormally low pressure classification (see Fig. 5). Hydrochemical characteristics can reveal the evolution of flow systems and if the formation is closed or 


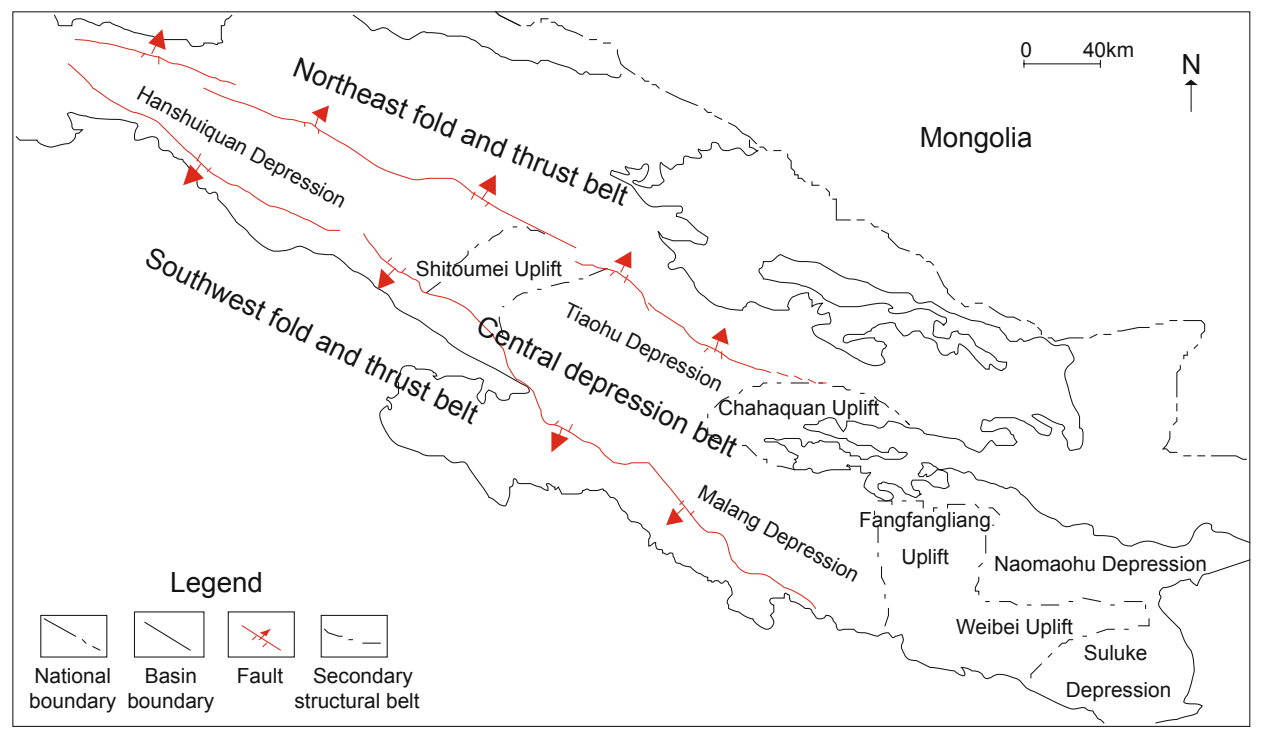

Fig. 3 Division of tectonic units of the Santanghu Basin

Table 1 Stratigraphic table of the Santanghu Basin

\begin{tabular}{|c|c|c|c|c|c|c|}
\hline \multicolumn{5}{|c|}{ Strata } & \multirow{2}{*}{$\begin{array}{l}\text { Thickness } \\
\mathrm{m}\end{array}$} & \multirow{2}{*}{ Description of lithology } \\
\hline Erathem & System & Series & Formation & Symbol & & \\
\hline \multirow{2}{*}{ Cenozoic } & Quaternary & & & Q & $40-60$ & Yellow conglomeratic clay and gravel \\
\hline & Tertiary & & & $\mathrm{R}$ & $35-161$ & $\begin{array}{l}\text { Non-isopachous interbeds of red brown mudstone and } \\
\text { gravel }\end{array}$ \\
\hline \multirow{6}{*}{ Mesozoic } & Cretaceous & Lower & & $\mathrm{K}_{1} \mathrm{tg}$ & $736-1052$ & $\begin{array}{l}\text { Chocolate brown mudstone, sandy mudstone with gray fine } \\
\text { siltstone and dark gray conglomerate }\end{array}$ \\
\hline & \multirow{4}{*}{ Jurassic } & Upper & Qigu Formation & $\mathrm{J}_{3} \mathrm{q}$ & $176-274$ & Mudstone and interbedded fine sandstone and siltstone \\
\hline & & \multirow[b]{2}{*}{ Middle } & Toutunhe Formation & $\mathrm{J}_{2} \mathrm{t}$ & $200-341$ & $\begin{array}{l}\text { Grayish green tuffaceous conglomerate mixed with brown } \\
\text { and chocolate brown tuffaceous conglomerate }\end{array}$ \\
\hline & & & Xishanyao Formation & $\mathrm{J}_{2} \mathrm{x}$ & $115-246$ & $\begin{array}{l}\text { Its upper part consists of coal; the middle upper part is } \\
\text { composed of gray mudstone; the middle lower part consists } \\
\text { of sandstone; and the lower part is composed of mudstone. }\end{array}$ \\
\hline & & Lower & $\begin{array}{l}\text { Sangonghe \& } \\
\text { Badaowan Formations }\end{array}$ & $\mathrm{J}_{1}$ & $30-200$ & $\begin{array}{l}\text { Gray sandstone and siltstone mixed with dark gray } \\
\text { mudstone }\end{array}$ \\
\hline & Triassic & Middle & Karamay Formation & $\mathrm{T}_{2} \mathrm{k}$ & $43-230$ & Mudstone and interbedded siltstone and fine sandstone \\
\hline \multirow{6}{*}{$\begin{array}{l}\text { Upper } \\
\text { Paleozoic }\end{array}$} & \multirow{2}{*}{ Permian } & \multirow[t]{2}{*}{ Upper } & Tiaohu Formation & $\mathrm{P}_{2} \mathrm{t}$ & $0-772$ & $\begin{array}{l}\text { The upper part is composed of dark gray mudstone and } \\
\text { the middle-lower part consists of gray andesite, basalt and } \\
\text { grayish green diabase. }\end{array}$ \\
\hline & & & Lucaogou Formation & $\mathrm{P}_{2} 1$ & $0-508$ & $\begin{array}{l}\text { Interbedded gray dolomite, dark gray tuffaceous mudstone } \\
\text { and calcareous mudstone }\end{array}$ \\
\hline & \multirow{4}{*}{ Carboniferous } & \multirow{3}{*}{ Upper } & Kalagang Formation & $\mathrm{C}_{2} \mathrm{k}$ & $540-1027$ & $\begin{array}{l}\text { Gray amygdaloidal vesicular basalt mixed with andesite, } \\
\text { gray and chocolate brown pyroclastic rock }\end{array}$ \\
\hline & & & Haerjiawu Formation & $\mathrm{C}_{2} \mathrm{~h}$ & $400-654$ & $\begin{array}{l}\text { The upper part consists of gray and grey black mudstone } \\
\text { and tuffaceous sandstone and the lower part is composed } \\
\text { of gray basalt and andesite. }\end{array}$ \\
\hline & & & $\begin{array}{l}\text { Batamayineishan } \\
\text { Formation }\end{array}$ & $\mathrm{C}_{2} \mathrm{~b}$ & $1000-2150$ & $\begin{array}{l}\text { Gray and grayish green basalt and andesite mixed with } \\
\text { thin layers of gray sandstone and mudstone }\end{array}$ \\
\hline & & Lower & Jiangbasitao Formation & $\mathrm{C}_{\mathrm{l}} \mathrm{j}$ & $600-1900$ & $\begin{array}{l}\text { Grey black mudstone and interbedded dark gray and } \\
\text { grayish green siltstone and sandstone }\end{array}$ \\
\hline
\end{tabular}




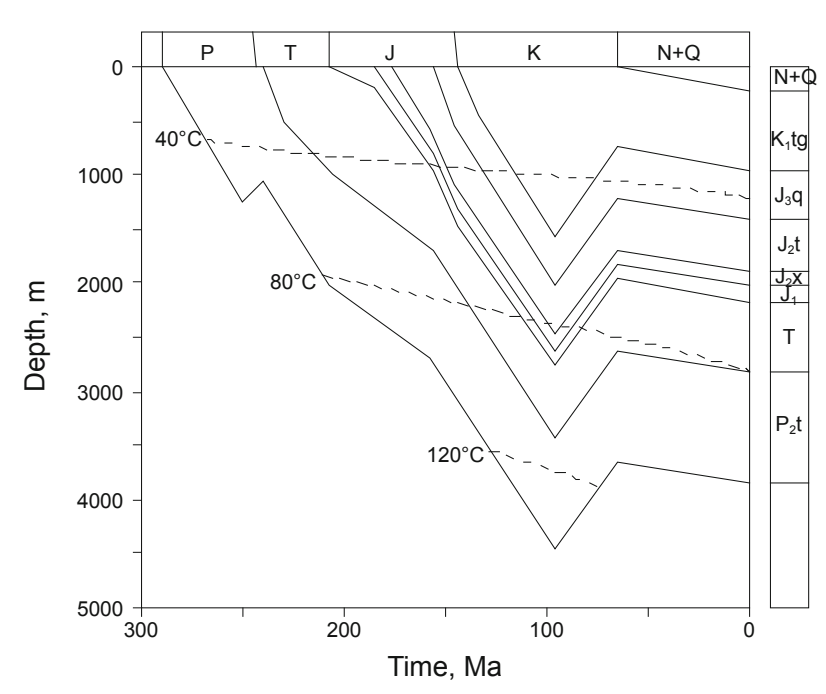

Fig. 4 Burial history curve of Well TC1

open hydrogeologically. Forty-three water samples from the Jurassic abnormally low-pressure reservoir are all of $\mathrm{CaCl}_{2}, \mathrm{MgCl}_{2}$ and $\mathrm{NaHCO}_{3}$ type, representing a retained hydrogeological condition, which suggests that the Jurassic abnormally low-pressure reservoir is closed and fluids have not flowed into or out of the reservoir.

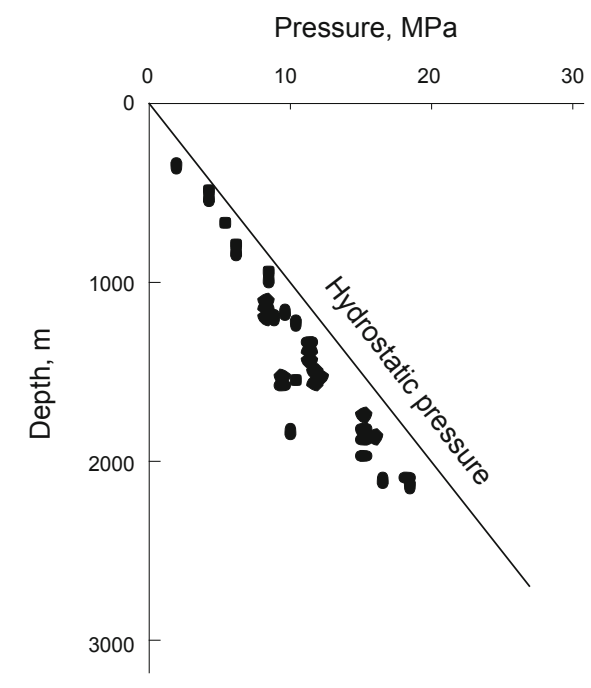

Fig. 5 Longitudinal distribution of formation pressure of Jurassic strata in the Santanghu Basin

\subsection{Influence of tectonic uplift-erosion on formation pressure in the Santanghu Basin}

Serebryakov and Chilingar (1994) thought that pore rebounding and fluid temperature decrease caused by tectonic uplift-erosion made the pressure of reservoirs in the Powder River Basin decrease by 8.3-11.9 MPa and 11.2-15.7 MPa respectively. In this research, it is assumed that the fluid in pores is formation water and the tests show that average compressibility coefficient of volume $\left(\beta_{\mathrm{r}}\right)$ of the rock sample is $26 \times 10^{-4} \mathrm{MPa}^{-1}$, and Poisson's ratio $(v)$ of consolidated rock is 0.25 . The analysis of continuous core samples from well M5 in Jurassic strata shows that the average density of strata $\left(\rho_{\mathrm{r}}\right)$ is $2,320 \mathrm{~kg} / \mathrm{m}^{3}$, compressibility coefficient of volume $\left(\beta_{\mathrm{f}}\right)$ of formation water is $5 \times 10^{-4} \mathrm{MPa}^{-1}$ (Dobrynin and Serebryakov, 1989), and the average coefficient of thermal expansion $\left(\alpha_{\mathrm{f}}\right)$ is $5 \times 10^{-4} \mathrm{~K}^{-1}$.

The geothermal gradient in the Santanghu Basin after the Cretaceous is $2.4-2.8^{\circ} \mathrm{C} / 100 \mathrm{~m}$ (Hao et al, 2006). Based on the current temperature of the Jurassic reservoir, the temperature gradient is $2-2.4{ }^{\circ} \mathrm{C} / 100 \mathrm{~m}$, that is, since the late Yanshanian, the geothermal gradient in the basin has changed little and the basin has been slowly cooling down. In this research, we take the average value $2.4^{\circ} \mathrm{C} / 100 \mathrm{~m}$ as the geothermal gradient during tectonic uplift-erosion. The erosion thickness of strata is obtained using the acoustic time method and the decrease in temperature of the abnormally low-pressure reservoir is obtained through basin simulation. Based on Eq. (14), the current pressure of the abnormally low-pressure reservoirs in the Santanghu Basin is lower than the balance pressure (see Table 2), indicating that the pressure coefficient generally decreases after tectonic uplifting. Therefore, Eq. (6) can be used to calculate the change of pore pressure caused by porosity rebound and temperature drop (see Table 3).

Table 2 Balance pressure of Jurassic abnormally low-pressure reservoir in the Santanghu Basin

\begin{tabular}{cccccc}
\hline $\begin{array}{c}\text { Name } \\
\text { of well }\end{array}$ & Horizon & $\begin{array}{c}\text { Pressure } \\
\text { depth } \\
\mathrm{m}\end{array}$ & $\begin{array}{c}\text { Pressure } \\
\text { coefficient }\end{array}$ & $\begin{array}{c}\text { Pressure } \\
\text { MPa }\end{array}$ & $\begin{array}{c}\text { Balance } \\
\text { pressure } \\
\text { MPa }\end{array}$ \\
\hline M1 Well & $\mathrm{J}_{2} \mathrm{t}$ & 1150.47 & 0.68 & 8.39 & 17.72 \\
M1 Well & $\mathrm{J}_{2} \mathrm{t}$ & 1201 & 0.68 & 8.80 & 18.50 \\
M1 Well & $\mathrm{J}_{2} \mathrm{t}$ & 1200 & 0.65 & 8.39 & 18.48 \\
N101 Well & $\mathrm{J}_{2} \mathrm{t}$ & 1220 & 0.78 & 10.27 & 18.79 \\
M1 Well & $\mathrm{J}_{2} \mathrm{x}$ & 1543.5 & 0.52 & 8.60 & 23.77 \\
M13 Well & $\mathrm{J}_{2} \mathrm{x}$ & 1819 & 0.77 & 15.08 & 28.01 \\
M1 Well & $\mathrm{J}_{2} \mathrm{x}$ & 1540 & 0.7 & 11.64 & 23.72 \\
M3 Well & $\mathrm{J}_{2} \mathrm{x}$ & 1500 & 0.72 & 11.58 & 23.1 \\
N101 Well & $\mathrm{J}_{2} \mathrm{x}$ & 1495.2 & 0.73 & 11.75 & 23.03 \\
N103 Well & $\mathrm{J}_{2} \mathrm{x}$ & 1550 & 0.63 & 10.48 & 23.87 \\
Well T3 & $\mathrm{J}_{2} \mathrm{x}$ & 1162 & 0.66 & 8.25 & 17.89 \\
T2 Well & $\mathrm{J}_{2} \mathrm{x}$ & 1517 & 0.57 & 9.40 & 23.36 \\
TC1 Well & $\mathrm{J}_{1} \mathrm{~b}$ & 2074.97 & 0.81 & 18.19 & 31.95 \\
TC1 Well & $\mathrm{J}_{1} \mathrm{~b}$ & 2103.63 & 0.73 & 16.47 & 32.40 \\
\hline
\end{tabular}

\subsection{Pressure evolution history}

With the tectonic movement of the late Yanshanian period, mature hydrocarbon in deep formations migrates vertically along fault zones, and then flows laterally in reservoirs under the power of superpressure. This stage is the main hydrocarbon-filling period controlled by an overpressurefault. At this stage, the pore fluid pressure increases rapidly and gives rise to abnormally high pressure due to the great 
Table 3 Summary table of genesis of abnormally low pressure in the Santanghu Basin

\begin{tabular}{|c|c|c|c|c|c|c|c|c|c|c|c|}
\hline Well & Depth & Horizon & $\begin{array}{l}\text { Current } \\
\text { temperature } \\
{ }^{\circ} \mathrm{C}\end{array}$ & $\begin{array}{l}\text { Current } \\
\text { pressure } \\
\mathrm{MPa}\end{array}$ & $\begin{array}{l}\text { Current } \\
\text { pressure } \\
\text { coefficient }\end{array}$ & $\begin{array}{l}\text { Uplift } \\
\text { height } \\
\text { m }\end{array}$ & $\begin{array}{l}\text { Temperature } \\
\text { drop } \\
{ }^{\circ} \mathrm{C}\end{array}$ & $\begin{array}{c}\text { Pressure drop caused } \\
\text { by temperature } \\
\mathrm{MPa}\end{array}$ & $\begin{array}{l}\text { Pressure drop } \\
\text { caused by pore } \\
\text { rebound } \\
\mathrm{MPa}\end{array}$ & $\begin{array}{l}\text { Overall } \\
\text { pressure drop } \\
\mathrm{MPa}\end{array}$ & $\begin{array}{l}\text { Paleo- } \\
\text { pressure } \\
\text { coefficient }\end{array}$ \\
\hline N101 & 1221.41 & $\mathrm{~J}_{2} \mathrm{t}$ & 38.9 & 10.26 & 0.78 & 801 & 32 & 6.15 & 8.49 & 14.64 & 1.2 \\
\hline M3 & 1484.56 & $\mathrm{~J}_{2} \mathrm{X}$ & 46 & 11.76 & 0.72 & 881 & 34 & 6.54 & 9.34 & 15.88 & 1.14 \\
\hline M1 & 1540 & $\mathrm{~J}_{2} \mathrm{x}$ & 46.8 & 11.64 & 0.7 & 738.5 & 34 & 6.54 & 7.83 & 14.37 & 1.11 \\
\hline $\mathrm{TC} 1$ & 2090.19 & $\mathrm{~J}_{1} \mathrm{~b}$ & 63.4 & 18.27 & 0.78 & 608 & 27 & 5.19 & 6.44 & 11.63 & 1.08 \\
\hline $\mathrm{T} 2$ & 1521.2 & $\mathrm{~J}_{2} \mathrm{x}$ & 52.4 & 9.4 & 0.57 & 846 & 31 & 5.96 & 8.97 & 14.93 & 1 \\
\hline $\mathrm{T} 3$ & 1167.27 & $\mathrm{~J}_{2} \mathrm{t}$ & 40.7 & 8.25 & 0.66 & 939 & 37 & 7.12 & 9.95 & 17.07 & 1.17 \\
\hline
\end{tabular}

enrichment of fluid (Table 3), and the pressure coefficient is 1-1.2. However, with tectonic uplifting, porosity rebound, and fluid shrinking caused by temperature decrease, the hydrocarbon generation and fluid supplement capacity of underlying source rocks are weakened. Thus, the formation pressure decreases gradually, eventually becoming abnormally low pressure.

\section{Conclusions}

1) During the uplift-erosion, every set of strata has a balance pressure. When the current formation pressure is equal to the balance pressure, the pressure coefficient stays unchanged though the formation pressure will drop after tectonic uplift-erosion. When the formation pressure is higher than balance pressure, tectonic uplift-erosion tends to produce high pressure coefficient. When the current formation pressure is lower than balance pressure, tectonic uplift-erosion tends to generate abnormally low pressure. The balance pressure is the function of buried depth and has a positive correlation with buried depth. The current formation pressure of the Santanghu Basin is lower than balance pressure, so tectonic uplift-erosion caused a decrease in the pressure coefficient of strata.

2) Numerical simulation and case analysis indicate that during the uplift-erosion, the pressure drop of strata in a closed state caused by pore rebound and decrease of fluid temperature has a positive correlation with erosion thickness. Tectonic uplift-erosion in the late Yanshanian period made the pressure of the Jurassic abnormally low-pressure reservoirs in the Santanghu Basin decrease by 11.6-17.1 MPa, which is the main reason why the Jurassic reservoir in the basin is a low pressure reservoir.

\section{Acknowledgements}

This project was supported by the National Natural Science Foundation of China (No. 40802027), China "973" Project (No. 2009CB219604) and the Risk Innovation Foundation of PetroChina Co. Ltd. (No. 0706d01040102).

\section{References}

Bachu S and Underschultz J R. Large-scale underpressuring in the Mississippian-Cretaceous succession, southwestern Alberta Basin. AAPG Bulletin. 1995. 79(7): 989-1004

Chilingar G V, Serebryakov V A and Robertson J O. Origin and prediction of abnormal formation pressures. Elsevier Publishing Co.. 2002. 233

Dai L C, Liu Z, Zhao Y, et al. Study of the characteristics and origin of abnormally high pressure and abnormally low pressure in the Jiyang Depression. Earth Science Frontiers. 2003. 10(3): 159 (in Chinese)

Dobrynin V and Serebryakov V A. Geological Geophysical Methods for Prediction of Pressure Anomalies. Nedra, Moscow. 1989. 287

Hao J R, Liu Y Q, Feng Q, et al. The tectonic-thermal evolution of the Santanghu Basin. Journal of Northwest University (Natural Science Edition). 2006. 36(2): 290-294 (in Chinese)

$\mathrm{He} \mathrm{S}$, Middleton $\mathrm{M}$ and Tang $\mathrm{Z} \mathrm{H}$. Characteristics and origin of underpressure system in the Shiwu Fault Depression, south-east Songliao Basin, China. Basin Research. 2000. 12(2): 147-157

Jiang Z X, Pang X Q, Jin Z J, et al. Relationship between pore variation of reservoir and rebounding of sandstone during uplift and its application to the Daqing Oilfield. Earth Science-Journal of China University of Geosciences. 2004. 29(4): 420-426 (in Chinese)

Jiang Z X, Tian F H and Xia S H. Physical simulation experiments of sandstone rebounding. Acta Geologica Sinica. 2007. 81(2): 244-249 (in Chinese)

Luo X R and Vasseur G. Contributions of compaction and aquathermal pressuring to geopressure and the influence of environmental conditions. AAPG Bulletin. 1992. 76(9): 1550-1559

Michael $\mathrm{K}$ and Bachu S. Fluids and pressure distributions in the foreland basin succession in the west central part of the Alberta Basin, Canada: Evidence for permeability barriers and hydrocarbon generation and migration. AAPG Bulletin. 2001. 85(7): 1231-1252

Neuzil C E. Low fluid pressure within the Pierre Shale: A transient response to erosion. Water Resources Research. 1993. 29(6): 20072020

Parks K P and Toth J. Field evidence for erosion-induced underpressuring in Upper Cretaceous and Tertiary strata, west-central Alberta, Canada. Bulletin of Canadian Petroleum Geology. 1995. 43(3): 281-292

Peterson R. Rebound in the Bearpaw Shale, western Canada. Geological Society of America Bulletin. 1958. 69(6): 1113-1124

Serebryakov V A and Chilingar G V. Investigation of underpressured reservoirs in the Powder River Basin, Wyoming and Montana. Journal of Petroleum Science and Engineering. 1994. 11(3): 249-259

Sorenson R P. A dynamic model for the Permian Panhandle and Hugoton fields, western Anadarko Basin. AAPG Bulletin. 2005. 89(7): 921938

Swarbrick R E and Osborne M J. Mechanisms that generate abnormal pressures: an overview. In: Law B E, Ulmishek G F and Slavin V I, Abnormal Pressure in Hydrocarbon Environments. AAPG Memoir. Tulsa: AAPG. 1998. 13-43

Tian F H, Jiang Z X, Zhang X B, et al. A preliminary study of the contribution of rift-erosion to oil and gas accumulation. Acta Geologica Sinica. 2007. 81(2): 273-279 (in Chinese)

Wu Y P, Li Z D and Wang Y C. The formation mechanisms of abnormal 
pressure and factor in control of the coalbed gas in Qinshui Basin. Journal of China Coal Society. 2006. 31(4): 475-479 (in Chinese)

Xia X Y, Song Y and Fang D Q. Influence of tectonic uplift on formation pressure and genesis of the abnormal pressure in Kela-2 Gas Field. Natural Gas Industry. 2001. 21(1): 30-34 (in Chinese)

Xie X N, Jiao J J, Tang Z H, et al. Evolution of abnormally low pressure and its implications for the hydrocarbon system in the southeast uplift zone of the Songliao Basin, China. AAPG Bulletin. 2003. 87(1): 99-119

Xu H, Tang D Z, Zhang J F, et al. Mechanism of water table affecting reservoir pressure. Coal Geology \& Exploration. 2008. 36(5): 31-34 (in Chinese)

Xu H, Zhang J F, Tang D Z, et al. The study status and tendency of low pressure. Advances in Earth Science. 2009. 24(5): 506-511 (in Chinese)

Yuan J H and Liu G D. Distribution characteristics and formation process of Upper Paleozoic abnormally low pressure zones in the Ordos Basin. Oil \& Gas Geology. 2005. 26(6): $792-799$ (in Chinese)
Zeng Z P, Cai X Y and Zou H Y. Formation mechanism of underpressure strata and its effect on oil-gas accumulation. Acta Geoscientia Sinica. 2002. 23(3): 255-258 (in Chinese)

Zhang J F, Jia C Z, Xu H, et al. Controlling function of feldspar dissolution in the abnormally low-pressure in the Jurassic reservoir of Santanghu Basin. Acta Petrolei Sinica. 2009. 30(1): 33-37 (in Chinese)

Zhang J F. Geological characteristics and formation mechanism of Mesozoic abnormally low-pressure oil reservoir in the Santanghu Basin. Ph.D Thesis. Research Institute of Petroleum Exploration and Development. 2007 (in Chinese)

Zhang L K, Wang Z L and Yu Z P. Causes of subnormal pressure in the sedimentary basins. Petroleum Geology \& Experiment. 2004. 26(5): 422-426 (in Chinese)

Zou H Y, Hao F and Cai X Y. Summarization of subnormal pressures and accumulation mechanisms of subnormally pressured petroleum reservoirs. Geological Science and Technology Information. 2003. 22(2): 45-50 (in Chinese)

(Edited by Hao Jie) 